\title{
Wpływ nowożytnego antropocentryzmu na relację człowieka do przyrody. \\ Część 2
}

Słowa kluczowe: antropocentryzm, przyroda, człowiek, filozofia nowożytna. Key words: anthropocentrism, nature, human, Modern philosophy.

\section{Wprowadzenie}

Antropocentryzm wydaje się pojęciem kluczowym dla relacji człowiek-przyroda i prawdopodobnie najbardziej spornym w etyce środowiskowej. Badanie rozwoju myśli antropocentrycznej w perspektywie historycznej ma na celu pokazanie przebiegu procesu, który doprowadził do kryzysu ekologicznego - zarówno w aspekcie ogólnych trendów cywilizacyjnych, jak i trendów myślowych. Śledząc ten proces uwagę koncentruje się na myślach europejskiego kręgu kulturowego przede wszystkim dlatego, że to głównie tzw. cywilizacja zachodnia jest oskarżana o wywołanie obecnego kryzysu ekologicznego, co ma związek z jej wyraźnie antropocentrycznym charakterem.

W historii kultury europejskiego kręgu cywilizacyjnego dostrzegalny jest proces, który ostatecznie doprowadził do teoretycznego usprawiedliwienia odrębności człowieka względem przyrody. Wyróżnić można co najmniej kilka głównych etapów tego procesu: etap kultury przedfilozoficznej, etap greckiej kultury starożytnej, etap średniowiecznej kultury chrześcijańskiej oraz etap kultury nowożytnej (Łepko 2006: 137). O ile na poziomie magii i mitu nie ma różnicy między częścią i całością rozumianą w sensie człowieka i przyrody, o tyle złożone 
procesy kulturowe doprowadziły w Nowożytności do ich zantagonizowania. Fakt ten sugeruje, że człowiek niejako „dojrzewał” do tego, aby się z przyrody wyodrębnić.

Do charakterystycznych dla czasów nowożytnych zmian w postrzeganiu świata przyczyniło się wiele czynników, m.in. wypracowanie nowożytnej koncepcji nauki oraz związany z tym faktem rozwój techniki, a także przemiany społeczne, polityczne i kulturowe (Zięba 1998: 109). $\mathrm{Na}$ współczesne postrzeganie świata i człowieka wpłynęły, oprócz nowej koncepcji nauki i nowej koncepcji poznania, również nurty transcendujące człowieka ze świata oraz nurty podejmujące próby zbliżenia człowieka do natury.

\section{Jeana Jacques'a Rousseau hasło „powrotu do natury”}

W opozycji do nowożytnych poglądów hołubiących ludzką cywilizację, jej wytwory i postęp techniczny, pojawiały się też głosy zdecydowanie krytykujące ducha ekspansji i racjonalizmu. Poglądy te zwracały się ku przyrodzie jako szczególnemu i w pewnym sensie świętemu miejscu realizowania się człowieczeństwa.

Prekursorem naturalistycznie zorientowanych filozofów europejskich był Jan Jakub Rousseau, który wybitnych kontynuatorów znalazł między innymi wśród romantyków niemieckich z Fryderykiem W. J. Schellingiem na czele.

Rousseau wystąpił z programem radykalnie odcinającym się od oświeceniowego zachłyśnięcia mocą ludzkiego rozumu i panowania dzięki jego wytworom nad przyrodą. Głosił mianowicie hasło „powrotu do natury". Jednak rozumiał je inaczej niż to się powszechnie mu przypisuje.

Punktem wyjścia J. J. Rousseau było przekonanie, że człowiek tylko z natury swej jest dobry. Dobro to przejawia się w postępowaniu zgodnym z uczuciami i wrodzonymi skłonnościami (Legowicz 1991: 367). Problem tkwi w tym, że ta naturalna dobroć zostaje w człowieku stłamszona przez nieodpowiednie wychowanie i przez wytwory źle ukierunkowanej cywilizacji. Źródło takiej sytuacji ma się kryć w nieprawdziwej - bo niepełnej - wizji człowieka. Oświecenie przeceniało bowiem 
w człowieku rozum, zaniedbując jego sferę emocjonalno-uczuciową oraz duchową. Do natury ludzkiej należą zaś oprócz rozumu również emocje, intuicja, instynkty, duchowość (Tarnas 2002: 369), a także wolność. Ta ostatnia ma w najwyższym stopniu stanowić o człowieczeństwie, ponieważ warunkuje specyficzną tylko dla człowieka moralność (Palacz 1987: 157). J. J. Rousseau detronizował rozum, najwyższą zdolność człowieka upatrując w uczuciach (kształtowanie ich uczynił głównym celem wychowania), a rozeznanie moralne przypisując nie jemu, lecz sumieniu (Tatarkiewicz 1998: 152-153). To w uczuciach i sumieniu, a nie w umyśle, znajduje się prawda (Legowicz 1991: 368-369).

Człowiek staje się człowiekiem poprzez nieustanne realizowanie swojego człowieczeństwa. Proces ten odbywa się jednak zawsze w społeczeństwie - nie w samotności. Co więcej, dokonuje się poprzez odchodzenie od stanu pierwotnej natury ludzkiej. Ta „denaturalizacja” okazuje się aktem koniecznym, gdyż dopiero wchodząc w relacje $\mathrm{z}$ innymi, człowiek staje się rzeczywiście człowiekiem (Sikora 2001: 258, Palacz 1987: 154). Ponieważ człowiek może zrealizować swoje człowieczeństwo tylko w społeczeństwie ludzkim, dlatego musi odrzucić swoją „Zwierzęcość”, aby jego rozumność i moralność mogły się urealnić. Poza społeczeństwem nie ma bowiem moralności, odnosi się ona do relacji z innymi osobami. To życie z innymi ludźmi otworzyło przed człowiekiem świat wartości, ideałów i uczuć. Społeczność jest zatem niezbędna dla rozwoju człowieka. Równie niezbędne jest odpowiednie wychowanie osoby, to znaczy wychowanie jej zgodnie z jej indywidualną naturą, talentami, uzdolnieniami w poszanowaniu dla natury i jej praw oraz w posłuszeństwie wobec tego, co uczucia uznają za dobre (Legowicz 1991: 369, Tatarkiewicz 1998: 153).

Społeczeństwo odrywając człowieka od jego natury, chroni go tym samym przed ewentualnymi zagrożeniami zwierzęcego bytowania w świecie przyrody. Jest ono niejako rezultatem konfliktu człowieka ze środowiskiem. Życie społeczne uwolniło człowieka od wielu niebezpieczeństw oraz umożliwiło realizację pragnienia o podporządkowaniu sobie świata (Sikora 2001: 259).

J. J. Rousseau zauważa jednak ważkie problemy dotyczące ludzkiej natury. Jest ona mianowicie wewnętrznie skomplikowana i za- 
razem sprzeczna, ludzie zaś mają silną skłonność do egocentryzmu i prywaty. Z jednej strony człowiek z natury jest dobry - a z drugiej postępuje źle, pragnie wolności - a żyje zniewolony, dąży do szczęścia a życie jego przepełnione jest cierpieniem, wielbi rozum - a w postępowaniu kieruje się irracjonalnymi motywami. Człowiek jest rozdarty między dobrem mu wrodzonym a złem, które czyni jako istota zmysłowa i podlegająca namiętnościom. Innymi słowy, człowiek jako byt racjonalny jest obywatelem, podąża za zasadami moralnymi, natomiast jako byt zmysłowy jest osobą prywatną, przedkładającą dobro własne i swoich bliskich nad dobro powszechne. Rousseau krytykuje cywilizację, która wzmocniła w człowieku sferę zmysłową i przyczyniła się do silnego rozwoju prywaty i egocentryzmu jednostek (Sikora 2001: 257264).

Cywilizacja ma więc dwa oblicza: $\mathrm{z}$ jednej strony jest warunkiem człowieczeństwa i jako taka jest dobra, z drugiej zaś - jest źródłem zła i ludzkiego upadku moralnego. „Paradoks i tragizm cywilizacji - pisze A. Sikora - polega na tym, iż dając nam wielką szansę bycia człowiekiem pozbawia nas człowieczeństwa. (...) Te same przyczyny, które obudziły człowieczeństwo, jednocześnie zdemoralizowały ludzi i uczyniły ich gorszymi niż zwierzęta." (Sikora 2001: 259-260) Moralność i cywilizacja w jej obecnym kształcie są zatem zantagonizowane. Rozwój cywilizacyjny jest źródłem zła i dostarczycielem cierpień, powoduje wyobcowanie człowieka z natury (Tarnas 2002: 369). Niejako wbrew założeniom nie czyni też ludzi ani lepszymi, ani szczęśliwymi, a wręcz demoralizuje ich (Tatarkiewicz 1998: 151). Wszystko to, co obraca się przeciwko naturze, mając na celu jej przekształcanie i podporządkowanie człowiekowi, obraca się ostatecznie przeciwko niemu, stanowi źródło zła (Dębowski 1996: 96). J. J. Rousseau postuluje wobec tego przekształcenie cywilizacji i takie jej udoskonalenie, aby dobro jednostki łączyło się z dobrem ogółu wolnych i równych ludzi, aby możliwe było tworzenie świata przyjaznego człowiekowi - zgodnego z jego naturą (Sikora 2001: 262). Zagwarantować to miała dobrowolna umowa społeczna.

Ponieważ obecna cywilizacja wypacza człowieka, degeneruje go, trzeba ją odrzucić i stworzyć - wskutek dobrowolnej umowy między 
wolnymi i równymi ludźmi - cywilizację wspierającą rozwój człowieczeństwa. Należy powrócić do źródeł człowieczeństwa, stanu pierwotnego bytowania człowieka, w którym każdy kieruje się logiką uczuć a nie rozumu, w którym to serce dyktuje normy postępowania i sposoby współżycia z innymi ludźmi. Chodzi o powrót do prostoty, o wyzwolenie się od zdeprawowania, zbytniego pokomplikowania i fałszu w relacjach z ludźmi. „Powrót do natury” oznacza u J. J. Rousseau tworzenie takiego społeczeństwa, które wspomaga naturalny rozwój człowieka, uwzględnia jego uczucia i sumienie (Sikora 2001: 262, Legowicz 1991: 368). Nie chodzi więc o bezrefleksyjne cofanie się cywilizacji wstecz, lecz o przeformułowanie jej podstaw i celów.

Myśl J. J. Rousseau rozpoczęła ideologicznie nową epokę. Wskazywał on na niedoceniane dotychczas obszary życia ludzkiego i uświadamiał ludziom ich człowieczeństwo. Wzbudzał pragnienie życia w wolności i równości, stanowiących według niego najwyższe dobra moralne. Osadził etykę na niezależnych od dotychczasowych, bo naturalistycznie zorientowanych podstawach. Poglądy J. J. Rousseau znalazły szeroki oddźwięk i doprowadziły do zasadniczych zmian w metodyce wychowania, w ustrojach społecznych. Broniąc praw do kierowania się głosem uczuć przygotował grunt romantyzmowi (Legowicz 1991: 369, Tatarkiewicz 1998: 153-154).

Wkład J. J. Rousseau do różnych dziedzin kultury jest niebanalny, a jego uderzenie w podstawy oświeceniowego racjonalizmu nie do przecenienia. Dostrzec można jednak jednostronność jego poglądów, wypaczających rzeczywisty obraz człowieka. Skrajnemu uwielbieniu rozumu i cywilizacji przeciwstawił on drugą skrajność - uczucia i naturę (Tatarkiewicz 1998: 153-154). Człowiek żyje natomiast pomiędzy tymi dwoma biegunami, raz skłaniając się w jedną, kiedy indziej w drugą stronę.

Stanowisko J. J. Rousseau w potocznym pojmowaniu mogłoby wydawać się antyantropocentryczne: postulat powrotu do natury, odwołania się do uczuć, czyli tego co bardziej pierwotne w człowieku, detronizowanie rozumu. Jednak nawołuje on przecież ludzi do rozwijania w sobie człowieczeństwa, postuluje wychowanie, które uczyni ludzi bardziej moralnymi, ludzkimi istotami. Jak najbardziej J. J. Rousseau 
jest antropocentryczny i z antropocentrycznego punktu widzenia wzywa do tworzenia cywilizacji bardziej zgodnej z ludzkimi pragnieniami i możliwościami.

\section{Dowartościowanie przyrody w idealistycznym systemie Fryderyka Schellinga}

Kontynuatorem myśli dowartościowującej naturę był Fryderyk Wilhelm Joseph von Schelling, przedstawiciel nurtu krytykującego cywilizację $\mathrm{w}$ jej zastanej formie oraz postulującego budowę świata opartego na harmonii między ludźmi i całym Wszechświatem (Zięba 1998: 119).

W systemie F. W. J. Schellinga źródłem rzeczywistości jest Absolut, pojmowany jako najwyższa zasada, pierwotna jednia myśli i bytu, ducha i ciała. Absolut stwarza przyrodę wraz z tkwiącymi w niej możliwościami w celu, aby dokonać w niej samopoznania. Byt jest w tym ujęciu zmianą, wyłanianiem się coraz to nowych przyrodniczych form istnienia, poprzez które przejawia się, uzewnętrznia świat duchowy, Absolut. Przyroda jest więc „odyseją" ducha dążącego od nieświadomości i zewnętrzności do świadomości i wewnętrzności (Sikora 2001: 287-290, Legowicz 1991: 398, Web-02).

Duch stanowi podstawę ciągłości pomiędzy światem organicznym i nieorganicznym. Dzięki niemu Wszechświat tworzy jedność, która funkcjonuje i różnicuje się na zasadzie działających przeciwstawnie sił. Jedność oraz biegunowość bytu, zauważalne we wszystkich zjawiskach przyrodniczych, są zasadniczymi jego cechami (Tatarkiewicz 1998: 210, Legowicz 1991: 399, Web-01, Web-02). Zasada tożsamości myśli i bytu implikuje niemożliwość oddzielenia tego, co cielesne od tego, co duchowe, oraz tego, co świadome od tego, co nieświadome. Ponieważ przyrodę przenika samopoznający się duch, również w każdej istocie materialnej jest element duchowy. W miarę rozwoju przyrody stopniowo zyskuje on przewagę nad tym, co cielesne, a kulminację osiąga w człowieku. To w człowieku, w procesie rozwoju jego historii, kultury a szczególnie sztuki Absolut osiąga szczyt samopoznania (Tatarkiewicz 1998: 209, Sikora 2001: 288-290). 
Przyroda stanowi dla F. W. J. Schellinga siłę żywą i twórczą, jeden, przeniknięty duchem pan-organizm. Do jej właściwości należą życie, piękno i ład moralny (Legowicz 1991: 399). Charakteryzuje ją celowość, przejawiająca się w procesie stawania się i samorozwoju (Tatarkiewicz 1998: 209, Sikora 2001: 288-289).

Człowiek stanowi element tak pojętej przyrody (Web-01). Jest z nią nawet identyczny, gdyż dla przyrody swoista jest jedność całości i części, materii i ducha (Dębowski 1996: 106). Przyroda jest więc niezbędnym podłożem dla świata ludzkiego, zaś fundowanie tego świata stanowi sens i cel jej istnienia. Ta współzależność czyni z przyrody prawdziwą ojczyznę ludzkości, służącą człowiekowi w utrzymaniu i rozwojowi życia duchowego (Sikora 2001: 288-290, Legowicz 1991: 402).

Z drugiej strony człowiek przekracza naturę jako podmiot wolny i myślący w aktach poznawczych i moralnych. Duch czyni go bowiem bytem samoświadomym, zaś dając mu wolność, pozwala mu na uniezależnienie się od determinizmów cielesnych. W człowieku łączą się więc wykluczające się determinizm natury i wolność (Web-01). Wolność jest wyzwaniem dla człowieka, który musi wybierać między dobrem i złem. Wybierając zło, człowiek niszczy nie tylko siebie, ale i zakłóca harmonię Wszechświata (Dębowski 1996: 107, Sikora 2001: 289-290).

W podejściu do przyrody stanowisko F. W. J. Schellinga było przełomowe. Między innymi dlatego, że odnosiło się krytycznie do charakterystycznej dla nowożytnego przyrodoznawstwa mechanistyczno-matematycznej wizji świata oraz utylitarnego stosunku do przyrody. Przeciwstawiało materialistycznym i mechanistycznym wizjom przyrody ujęcie przyrody przenikniętej duchem. Teza o jedności całego świata z Absolutem implikowała zaś odrzucenie pokusy panowania człowieka nad przyrodą oraz jej instrumentalnego traktowania (Dębowski 1996: 107, Tatarkiewicz 1998: 209-210).

Również w wizji F. W. J. Schellinga obecne jest antropocentryczne spojrzenie na rzeczywistość. Chodzi o umiejscowienie człowieka w szczególnym punkcie przecięcia się nieświadomej samej siebie rzeczywistości materialnej z rzeczywistością samoświadomego ducha, sa- 
mopoznającego się Absolutu. Nie mniej antropocentryczne jest uznanie człowieka za ukoronowanie rozwoju Absolutu w rzeczywistości.

Zarówno J. J. Rousseau, jak i F. W. J. Schelling w swoich próbach przywrócenia człowieka naturze oraz natury człowiekowi nie uniknęli więc wizji antropocentrycznej. Zresztą nie o to w ich koncepcjach chodziło. Istotne w tych próbach „powrotu do natury” jest przewartościowanie relacji człowiek-przyroda i uznanie w przyrodzie wartości niezależnej od ludzkiego punktu widzenia. Równie ważne jest również przywrócenie holistycznego spojrzenia na świat i uznanie, że przyroda jest systemem, którego złożoność i funkcjonalność jakościowo przekraczają zsumowane właściwości elementów składowych.

\section{Wpływ myśli nowożytnej na współczesne postrzeganie miejsca człowieka w przyrodzie}

Historyczne ujęcie rozwoju myśli filozoficznej europejskiego kręgu kulturowego sugeruje, że myśl antropocentryczna rozwijała się stopniowo. Współczesna cywilizacja jest rezultatem tego procesu.

Usprawiedliwianie panowania człowieka nad przyrodą jest charakterystycznym rysem całego myślenia zachodnioeuropejskiego i nie ogranicza się tylko do czasów nowożytnych czy współczesnych. Te jedynie ujawniły skutki znacznie wcześniej kultywowanych form dominacji człowieka nad otoczeniem przyrodniczym. Już mityczne opisy przyrody stanowiły bowiem wyraz tej dominacji, utrwalanej następnie za pomocą filozofii, nauki i techniki (Łepko 1998: 62). Zasadnicze zmiany w pojmowaniu miejsca i sensu istnienia człowieka w świecie dokonywały się jednak dopiero wraz z rozwojem ludzkiej wiedzy na ten temat. O ile w Starożytności wiedza była raczej uboga i słabo związana z praktyką życia codziennego, o tyle w epoce nowożytnej nastąpił gwałtowny przyrost wiedzy o świecie, a zmiany w obrazie świata oraz umiejscowieniu w nim człowieka były rewolucyjne. Nastąpiło też daleko idące upraktycznienie zdobytej wiedzy, związane z wykorzystaniem jej dla ekspansji gatunku ludzkiego oraz ujarzmianiem przyrody. W ten sposób przekonanie o zależności człowieka od przyrody, funkcjonujące w świadomości europejskiej do XIV-XVI wieku, ustąpiło ludzkiemu 
dążeniu do podporządkowania sobie przyrody. Kult przyrody zamienił się wówczas na kult człowieka i panowanie światopoglądu antropocentrycznego (Dębowski 1996: 77).

Renesansowi myśliciele częstokroć intensywnie przeżywali stosunek człowieka do Wszechświata. Wszechświat był bowiem według nich wypełniony życiem, światłem i myślą. Rozwijając mechanistyczny obraz świata wykraczali więc poza jego czasoprzestrzenne ramy i poszukiwali jakiejś rządzącej nim zasady ogólnej. Stąd w renesansowych filozofiach przyrody odnaleźć można zarówno model przyrody jako mechanizmu, jak i model organizmu. Na przykład ludzkie ciało miało być wyrazem ładu panującego we Wszechświecie i jako takie było przedmiotem zachwytu (Dębowski 1996: 48-49 i 67).

Nowożytność natomiast zerwała ostatecznie ze średniowiecznym teocentryzmem i starożytnym geocentryzmem. Skierowała się ku człowiekowi, jego potrzebom, możliwościom i wytworzyła swoisty typ antropocentryzmu, polegający na poszukiwaniu odpowiedzi na zagadki bytu w samym człowieku. Skutkowało to odrzuceniem przeświadczenia o ścisłej zależności człowieka od przyrody oraz dążeniem do podporządkowania sobie przyrody, traktowanej teraz czysto mechanistycznie (Dębowski 1996: 65).

Odrzucenie dotychczasowej uniwersalistycznej wizji świata zmodyfikowało zarówno rozumienie człowieka, świata jak i Boga. O ile jeszcze Kartezjusz pojmował człowieka jako istotę wolną duchem od determinizmu materii, o tyle w następnych wiekach podporządkowano mu już całego człowieka. Stworzono mechanistyczną i racjonalistyczną wizję człowieczeństwa, a samego człowieka zaczęto traktować jako jedną z rzeczy. Dokonując samodegradacji człowiek zinstrumentalizował nie tylko przyrodę, ale i samego siebie (Dębowski 1996: 66-68). Co więcej, wytwory natury i wytwory ludzkie zyskały równy status. Mianowicie maszyn podległym prawom mechaniki.

W Nowożytności filozofia przestała być dyscypliną niezależną. Zaczęto ją określać w odniesieniu do nauki - przede wszystkim jako jej dyscyplinę pomocniczą. Od tej pory to nauka opisywała Wszechświat: jako materialny, mechanistyczny i uporządkowany matematycznie. Nauka opisywać zaczęła również człowieka: jako istotę racjonalną, 
zdolną pojąć swoim umysłem prawa rządzące przyrodą i wykorzystać ich znajomość do zapanowania nad nią (Tarnas 2002: 331). Pole badawcze nauki zawęziło się jednak i ograniczyło głównie do analizy poszczególnych elementów rzeczywistości. Pomijano więc zarówno jej aspekt całościowy, jak i aspekt jej ewentualnej hierarchiczności czy celowości. Zaprzeczenie istnieniu celowości w przyrodzie odebrało przesłanki do jej wartościowania i odpowiedzialności wobec niej, a na pierwszy plan wysunęło przygodność świata (Zięba 1998: 113-114).

Oświecenie rozwinęło w sposób szczególny ideę postępu cywilizacyjnego ludzkości. Takie ukierunkowanie działań ludzkich stopniowo usuwało ze świadomości ideę Boga i Opatrzności czuwającej nad biegiem dziejów ludzkich. Zastępowała je wizja człowieka jako twórcy wszelkiego postępu. Świadomość stanowienia przez ludzkość cząstki przyrody zanikała zaś na rzecz pojmowania egzystencji ludzkiej jako wyizolowanej ze środowiska i przebiegającej w horyzoncie społecznej i usensownionej historii dziejów. Postępująca racjonalizacja mentalności oraz sekularyzacja społeczeństw europejskich uczyniły człowieka najważniejszym i jedynym punktem odniesienia dla całej rzeczywistości. Stąd jego wartościowanie moralne przestało odnosić się do sfery pozaludzkiej (Dębowski 1996: 88-90).

Na współczesną wrażliwość wpłynęło to wzajemne oddziaływanie na siebie myśli oświeceniowej i romantycznej. Obie mentalności różniło zarówno rozumienie natury, jak i spojrzenie na człowieka. Dla naukowej umysłowości Oświecenia przyroda stanowiła przedmiot badań empirycznych, wyjaśnień teoretycznych oraz technicznych manipulacji. Dla umysłowości romantycznej, przeciwnie, przepełniona duchem natura była źródłem tajemnicy i objawienia. Rzeczywistość dla uczonego była konkretna, jednoznaczna, dosłowna. Dla romantyka była zaś na wskroś symboliczna, wieloznaczna, nawet pełna sprzeczności. Podobnie jak uczeni Oświecenia, romantycy również poszukiwali zasad porządkujących i jednoczących, nadających sens przyrodzie. Jednak dla poszerzenia obrazu rzeczywistości oprócz zmysłów i rozumu zaprzęgali do pracy nad jego poznawaniem wyobraźnię, uczucie i wolę (Tarnas 2002: 435-437). 
Z biegiem czasu obie wizje, romantyczna i oświeceniowa, doprowadziły do rozdwojenia w zachodnim obrazie świata. Średniowieczna dychotomia rozumu i wiary, a następnie nowożytna dychotomia świeckiej nauki i religii chrześcijańskiej przerodziły się w ogólniejszą schizmę: kultury humanistycznej oraz naukowego racjonalizmu. Nastąpił radykalny podział na dyscypliny humanistyczne i nauki przyrodnicze. $\mathrm{Z}$ powodu tego podziału człowiek zaczął doświadczać coraz mocniejszego rozdarcia między swoim umysłem i duszą. Starając się bowiem przyjmować zarówno światopogląd naukowy, jak i humanistyczno-religijny, nie był w stanie stworzyć z nich spójnej wizji rzeczywistości.

Wskutek tego dualizmu ludzkie doświadczenie przyrody oraz relacja do niej zaczęły ulegać paradoksalnym zmianom. Oba nurty stopniowo zaczęły pogrążać człowieka w przyrodzie. Romantyzm poprzez dążenie do świadomego zjednoczenia $\mathrm{z}$ naturą. Oświecenie poprzez naturalistyczny opis człowieka przez naukę. Z tym, że w naukowym, darwinowsko-freudowskim ujęciu antagonizm człowieka i natury, przejawiający się w eksploatacji i podporządkowywaniu natury, stanowił nieuchronną konsekwencję biologicznej ewolucji człowieka i jego wyłonienia się z przyrody. Antagonizm ten wyzwolił w człowieku poczucie wyobcowania z natury i utratę z nią jedności. Człowiek stał się nadwrażliwym mieszkańcem bezlitosnego, pozbawionego zarówno cech osobowych, jak i ludzkich, ogromu (Tarnas 2002: 442-447). Niemożliwe stało się połączenie ze sobą totalnie odległych ludzkiej świadomości i nieświadomego Wszechświata: „owego wewnętrznego podziału zaczęto doświadczać jako alienacji wrażliwej ludzkiej psychiki usytuowanej w świecie wyobcowanym z ludzkiego sensu. Człowiek nowoczesny był rozdartym zwierzęciem, w sposób niewytłumaczalny samoświadomym w obojętnym wszechświecie" - pisze R. Tarnas (Tarnas 2002: 445-446). 


\section{Uwagi końcowe}

Należy podkreślić, że kierunek rozwoju cywilizacji zachodniej rozminął się ze swym celem, jakim z założenia jest dobro ludzkości. Nowożytna nauka jest uprawiana w sposób agresywny i manipulacyjny, dążący do narzucania swojej wizji rzeczywistości i przekształcania tej ostatniej zgodnie z naukowym obrazem świata. Nauka, pozbawiona elementu kontemplacji przyrody, stała się wroga człowiekowi i jego potrzebie odnajdywania sensu w rzeczywistości (Łepko 1998: 60-61). Nie sposób przecenić wpływu myśli filozoficznej na obecny kształt dominującej kultury zachodniej, ukształtowanej według antropocentrycznego paradygmatu naukowo-technicznego. Współczesne zaburzone relacje człowieka ze środowiskiem przyrodniczym, ale również społecznym, są niewątpliwie efektem promowania i realizowania tegoż właśnie paradygmatu.

Artykuł stanowi część cyklu o historii rozwoju antropocentryzmu. Pierwsza część pt. Mityczno-magiczne źródła antropocentryzmu, ukazała się w „SEMINARE” 23 (2006), s. 109-120, druga pt. Starożytne źródła antropocentryzmu ukazała się w „Studia Ecologiae et Bioethicae” 7(2009)2, s. 31-38, Średniowieczne źródła antropocentryzmu zostały przyjęte do „Studia Ecologiae et Bioethicae” 9(2011), czwarta pt. Nowożytne źródła antropocentryzmu. Część pierwsza ukazała się w „Studia Ecologiae et Bioethicae” 9(2011)1, s. 9-27.

\section{Bibliografia}

Dębowski J., 1996, Filozoficzne źródła refleksji ekologicznych, Olsztyn.

Gloy K., 1995, Das Verständnis der Natur. Erster Band. Die Geschichte des wissenschaftlichen Denkens, München.

Legowicz J., 1991, Zarys historii filozofii. Elementy doksografii, Warszawa.

Leśniak K., 1967, Franciszek Bacon, Warszawa.

Łepko Z., 2006, Problem opozycji człowieka wobec przyrody, SEMINARE 23(2006), s. 137-148.

Łepko Z., 1998, Spór o testament Bacona, SPCh, 34 (1998) 2, s. 53-74.

Palacz R., 1987, Klasycy filozofii, Warszawa.

Sikora A., 2001, Od Heraklita do Husserla. Spotkania z filozofia, Warszawa.

Tarnas R., 2002, Dzieje umysłowości zachodniej. Idee, które ukształtowaly nasz światopoglad, tłum. M. Flipczuk, Poznań. 
Tatarkiewicz W., 1998, Historia filozofii. Tom II. Filozofia nowożytna do roku 1830, Warszawa.

Zięba S., 1998, Natura i człowiek w ekologii humanistycznej, Lublin.

\section{Witryny internetowe}

(Web-01) Bowie A., Friedrich Wilhelm Joseph von Schelling, w: Stanford Encyclopedia of Philosophy, <http://plato.stanford.edu/entries/schelling>, dostęp: 19.06.2006.

(Web-02) Hartman J., Słownik filozofii, <http://www.iphils.uj.edu.pl/ j.hartman/ slownik_fil.php>, dostęp: 16.06.2006.

\section{The Modern Sources of Anthropocentrism. Part two}

\section{SUMMARY}

Anthropocentrism seems to be a fundamental notion concerning the mannature relation. The anthropocentric attitude is largely meant to be the main cause of the ecological crisis. One can distinguish at least several stages of the process, which led to this crisis, namely: stage of Magic and Myth, Ancient Times, Middle Ages and Modern Times. The aim of this article is to show the process of development of an anthropocentric thought in the Modern European culture, when the culmination of this process is observed.

Among the causes of the modern worldview one can mention e.g. the modern conception of science, the technology development, as well as social, political and cultural changes.

Contemporary view on nature and man was influenced not only by mechanistic and materialistic theories tending to subordinate nature to man (G. Bruno, F. Bacon, R. Descartes) but also by philosophical views which on the one hand excluded man from nature (I. Kant) and on the other made attempts to restore man to nature (J. J. Rousseau, F. W. J. Schelling). 